\title{
Thermal shock and splash effects on burned gypseous soils from the Ebro Basin (NE Spain)
}

\author{
J. León ${ }^{1}$, M. Seeger ${ }^{2,4}$, D. Badía ${ }^{3}$, P. Peters ${ }^{2}$, and M. T. Echeverría ${ }^{1}$ \\ ${ }^{1}$ Dept. of Geography and Land Management, University of Zaragoza, Spain \\ ${ }^{2}$ Soil Physics and Land Management, Wageningen University, the Netherlands \\ ${ }^{3}$ Dept. of Agricultural Science and Environment, University of Zaragoza, Spain \\ ${ }^{4}$ Physical Geography, Trier University, Germany
}

Correspondence to: J. León (fcojleon@unizar.es)

Received: 17 September 2013 - Published in Solid Earth Discuss.: 30 October 2013

Revised: 27 January 2014 - Accepted: 31 January 2014 - Published: 12 March 2014

\begin{abstract}
Fire is a natural factor of landscape evolution in Mediterranean ecosystems. The middle Ebro Valley has extreme aridity, which results in a low plant cover and high soil erodibility, especially on gypseous substrates. The aim of this research is to analyze the effects of moderate heating on physical and chemical soil properties, mineralogical composition and susceptibility to splash erosion. Topsoil samples (15 cm depth) were taken in the Remolinos mountain slopes (Ebro Valley, NE Spain) from two soil types: Leptic Gypsisol (LP) in a convex slope and Haplic Gypsisol (GY) in a concave slope. To assess the heating effects on the mineralogy we burned the soils at 105 and $205^{\circ} \mathrm{C}$ in an oven and to assess the splash effects we used a rainfall simulator under laboratory conditions using undisturbed topsoil subsamples (0-5 cm depth of Ah horizon). LP soil has lower soil organic matter (SOM) and soil aggregate stability (SAS) and higher gypsum content than GY soil. Gypsum and dolomite are the main minerals $(>80 \%)$ in the LP soil, while gypsum, dolomite, calcite and quartz have similar proportions in GY soil. Clay minerals (kaolinite and illite) are scarce in both soils. Heating at $105^{\circ} \mathrm{C}$ has no effect on soil mineralogy. However, heating to $205^{\circ} \mathrm{C}$ transforms gypsum to bassanite, increases significantly the soil salinity (EC) in both soil units (LP and GY) and decreases pH only in GY soil. Despite differences in the content of organic matter and structural stability, both soils show no significant differences $(P<0.01)$ in the splash erosion rates. The size of pores is reduced by heating, as derived from variations in soil water retention capacity.
\end{abstract}

\section{Introduction}

Fire is a natural factor of landscape evolution in Mediterranean ecosystems. Forest fires change the vegetation cover, the soil properties and trigger higher erosion rates that can contribute to rejuvenate the gullies (Hyde et al., 2007). The important socioeconomic changes that occurred in the last decades have contributed to an increase in forest fires (Shakesby, 2011), altering the fire regimes in terms of frequency, size, seasonality and recurrence as well as fire intensity and severity (Keeley, 2009; Doerr and Cerdà, 2005) causing severe effects on soils, water and vegetation (BentoGonçalves et al., 2012; Guénon et al., 2013).

Fire affects soil properties directly by heat impact and ash incorporation and reduction or elimination of plant cover (Bodí et al., 2014). Raindrop impact on burnt soil can lead to the structural degradation of the soil surface (Bresson and Boiffin, 1990; Poesen and Nearing, 1993; Ramos et al., 2003). Aggregate breakdown liberates small soil particles forming a surface crust with low permeability to air and water (Llovet et al., 2008; Mataix Solera et al., 2011). Fire severity affects the susceptibility of soils to degradation (Neary et al., 1999; Shakesby, 2011). The effects of heat on soil organic matter content (Mataix-Solera et al., 2002; GonzálezPérez et al., 2004), on structural stability (Mataix-Solera et al., 2011), on hydrophobic response (Bodí, 2012; Giovannini, 2012), and on infiltration capacity (Cerdà, 1998) have been also investigated. These characteristics represent factors in soil erodibility and soil degradation risk (Shakesby, 2011; Giovannini, 2012). This is why the vegetation cover 
and the litter are key factors on soil erosion after forest fires (Prats et al., 2013), which determines the debris flow formation (Riley et al., 2013). Besides, ash plays an important role in soil protection after the forest fire and after the first storms and winds (Cerdà and Doerr, 2008; León et al., 2013; Pereira et al., 2013).

In the central Ebro Valley (NE Spain), the tectonic history contributed to developing evaporative rock and then saline and gypsum soils (Dominguez et al., 2013). Moreover, the climate, lithology and relief promote the development of soils whose main constituent is gypsum $\left(\mathrm{CaSO}_{4} \cdot 2 \mathrm{H}_{2} \mathrm{O}\right)$, named gypseous soils (Herrero and Porta, 2000), occupying $7.2 \%$ of the total area (Aznar et al., 2013a). The global distribution of gypseous soils is associated with regions of arid and semiarid climate (FAO, 1990; Verheye and Boyadgiev, 1997) represents edaphic modifications that exert strong effects in this important agricultural area of the central Ebro Valley. Moreover, the gypseous are common through out the badlands within Mediterranean environments and represent the dominant sediment source within these areas (Nadal et al., 2013).

Temperature controls some of the changes that occur in the soil as a result of the fire: protein degradation and biological tissue death at $40-70^{\circ} \mathrm{C}$; dehydration of roots or death at 48 $54^{\circ} \mathrm{C}$; death of seeds at $70-90^{\circ} \mathrm{C}$; death of edaphic microorganisms at $50-121^{\circ} \mathrm{C}$; and destructive distillation and combustion of about $85 \%$ of the organic horizon at $180-300^{\circ} \mathrm{C}$ (Neary et al., 1999). In terms of temperatures attained during actual fires, Pérez-Cabello et al. (2012) measured maximum values between $400-800^{\circ} \mathrm{C}$ during a prescribed fire, and heat transfer values of up to $110^{\circ} \mathrm{C}$ during controlled burn plots in semiarid shrubland. The lower temperatures are associated with low vegetation cover characterized by small shrub patches on gypseous soils. Although the temperatures reached in burned semiarid woodlands may not be very high, they may be enough to cause some edaphic changes. Research on gypseous soils has focused on genesis and classification (Herrero and Porta, 2000; Badía et al., 2013), plant recovery (Badía and Martí, 2000), erosion processes (Gutiérrez and Gutiérrez, 1998) and mineralogy (Herrero and Porta, 2000; Herrero et al., 2009), but few studies address postfire hydrological response (León et al., 2011) and erodibility (León et al., 2012).

Rainfall simulations are a remarkably useful tool to assess changes on soil properties and erosion by raindrop impact, especially in semiarid areas, where the precipitation regime is irregular, having intense and short-duration events (Seeger, 2007; Cerdà et al., 2009; León et al., 2012).

The aim of this research is to analyze the heating effects of a moderate fire on physical, chemical soil properties, mineralogical composition and susceptibility to splash erosion by simulated rainfall.

\section{Materials and methods}

\subsection{Study area}

The gypseous soils were sampled in the Zuera Mountains in the central sector of the Ebro Basin (NE Spain) near the town of Remolinos. This area has been regularly affected by wildfires that promoted the development of shrub communities (Retama sphaerocarpa L., Rosmarinus officinalis L., Lygeum spartum, Gypsophila struthium subsp. hispanica and Ononis tridentata) and small patches of forest (Pinus halepensis Mill. with an understory of Quercus coccifera L.), covering the north slopes (Ruiz, 1990).

The research sites were selected on irregular relief (200$748 \mathrm{~m}$ ), where gypseous soils predominate on the low elevation slopes (Badía et al., 2013). The climate is continentalMediterranean, with a mean annual precipitation up to $450 \mathrm{~mm}$, with maxima autumn, spring and extreme temperatures that can vary between -7.1 and $36.5^{\circ} \mathrm{C}$. The mean annual evapotranspiration reaches $1200 \mathrm{~mm}$ (using FAO56 by the Penman-Monteith method) and it is enhanced by strong winds, which makes the water deficit to be one of the highest in Europe (Herrero and Synder, 1997).

\subsection{Soil sampling and preparation}

Topsoil blocks $(20 \mathrm{~cm} \times 20 \mathrm{~cm} \times 15 \mathrm{~cm})$ were sampled in two different geomorphic position at the head of the slope with unburned gypseous soils, classified as Leptic Gypsisol (skeletic) by IUSS (2007), with a sequum Ahy-R (which we will call henceforth LP), and at the foot of the slope, with burned gypseous soils, Haplic Gypsisol (humic) with a sequum Ah-By-Cy (which we will call henceforth GY). The soils are described in more detail in Badía et al. (2013). The samples had different textures: GY was sandy loam, and LP was loamy. The GY topsoil has a different distribution of the main mineralogical components; gypsum, dolomite, calcite and quartz were around 18-25\% each. Gypsum and dolomite are the main minerals $(>80 \%)$ in the LP topsoil. Clay minerals (kaolinite and illite) are scarce in both soils.

Fifteen replicates of each soil block were taken in clean cylinders $(5 \mathrm{~cm} \times 6 \mathrm{~cm})$ and closed at the bottom with a metallic plate (Fig. 1). The samples were dried for one month at $25^{\circ} \mathrm{C}$, under controlled conditions, and heated to $35^{\circ} \mathrm{C}$ (all samples), $105^{\circ} \mathrm{C}$ (ten samples of each soil) and $205^{\circ} \mathrm{C}$ (five samples of both soils) for $30 \mathrm{~min}$ to observe the soil changes after the heating.

\subsection{Rainfall simulation}

We used a portable rainfall simulator with a Lechler nozzle (Ref. 460.608.30) at $2 \mathrm{~m}$ height (Iserloh et al., 2011), in the Kraaijenhofvan de Leur Laboratory for water and sediment dynamics at Wageningen University. Small rainfall collectors were used for the detailed determination of the rainfall intensity on the simulation area $\left(1.16 \mathrm{~m}^{2}\right)$. Drop size 


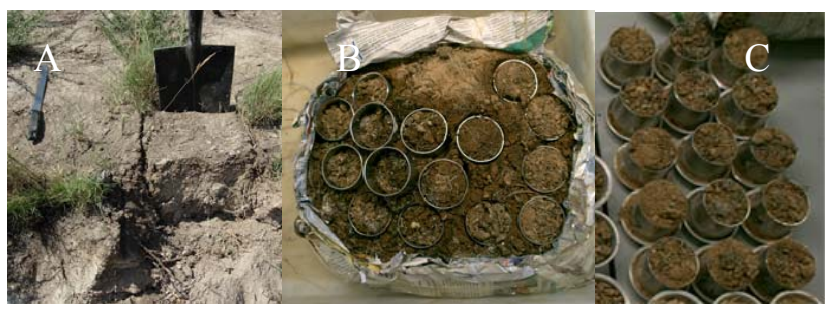

Fig. 1. Sample preparation: (A) block extraction, (B) subsamples of the blocks; and (C) sub-sample preparation.

$\left(d_{50} 1-1.5 \mathrm{~mm}\right)$ and the kinetic energy $\left(5.81 \mathrm{~J} \mathrm{~m}^{-2} \mathrm{~mm}^{-1}\right)$ were measured with a Thies laser disdrometer (Fister et al., 2011). The simulation time was $20 \mathrm{~min}$ with rain intensity of $53 \mathrm{~mm} \mathrm{~h}^{-1}$ and demineralized water (with $\mathrm{pH} 7.1$ and EC (soil salinity) of $36.7 \mu \mathrm{S} \mathrm{cm}^{-1}$ ) was used. The simulation plot was divided into four subplots that previously were calibrated with the laser disdrometer (Fig. 2).

\subsection{Soil analysis}

Eight parameters were measured on the gypseous soils: $\mathrm{pH}$, EC, soil organic matter (SOM), gypsum content (GC), soil aggregates stability (SAS), matric potential ( $\mathrm{pF}$ or $\left.\Psi_{\mathrm{p}}^{\mathrm{m}}\right)$, soil texture and mineralogy of fine fraction $(<2 \mathrm{~mm})$.

Soil samples were sieved to $2 \mathrm{~mm}$. The $\mathrm{pH}$ was measured in a $1: 5$ dilution with distilled water with a $\mathrm{pH}$ meter, while the EC was measured in a $1: 10$ dilution $\left(25^{\circ} \mathrm{C}\right)$, with a conductivimeter after filtering the diluted sample (pore size filter $0.45 \mu \mathrm{m})$. For measuring SOM by weight difference, about $30 \mathrm{~g}$ of material was crushed and sieved to $2 \mathrm{~mm}$, dried at $105^{\circ} \mathrm{C}(24 \mathrm{~h})$ and heated to $550{ }^{\circ} \mathrm{C}(3 \mathrm{~h})$. SOM was measured by gravimetry. Gypsum content was measured by thermo-gravimetry (Vieillefon, 1979; Herrero and Porta, 2000; Lebron et al., 2009). SAS was measured using an Eijkelkamp wet sieving device (Schinner et al., 1996). To measure the matric potential $(\mathrm{pF})$ we used sand box method of Eijkelkamp at $\mathrm{pF}$ 0, 1, 1.5 and 2. The volumetric pressure plate extractor (Richards, 1947) was used for measuring the $\mathrm{pF} 3$ and 4.2 by breaking up and sieving the sample to $2 \mathrm{~mm}$. The soil texture was measured with a Malvern Mastersizer 2000, correcting the clay value according to the Taubner et al. (2009) equation $(y=3089 x-2899)$. Mineralogical composition of the fine fraction $(<2 \mathrm{~mm})$ of each soil type and after each heat treatment was determined separately. The analysis was performed using a Siemens D500 diffractometer, in the laboratory of Geology at Trier University. The diffractograms were evaluated by Diffrac Plus Release 2000 EVA 6.0.0.1. The splash effect was measured by differences of weight, before and after the rainfall simulation and two weeks after the experiment, after air drying at $35^{\circ} \mathrm{C}$. To avoid loss of material by percolation, samples were closed at the bottom with a metal plate.

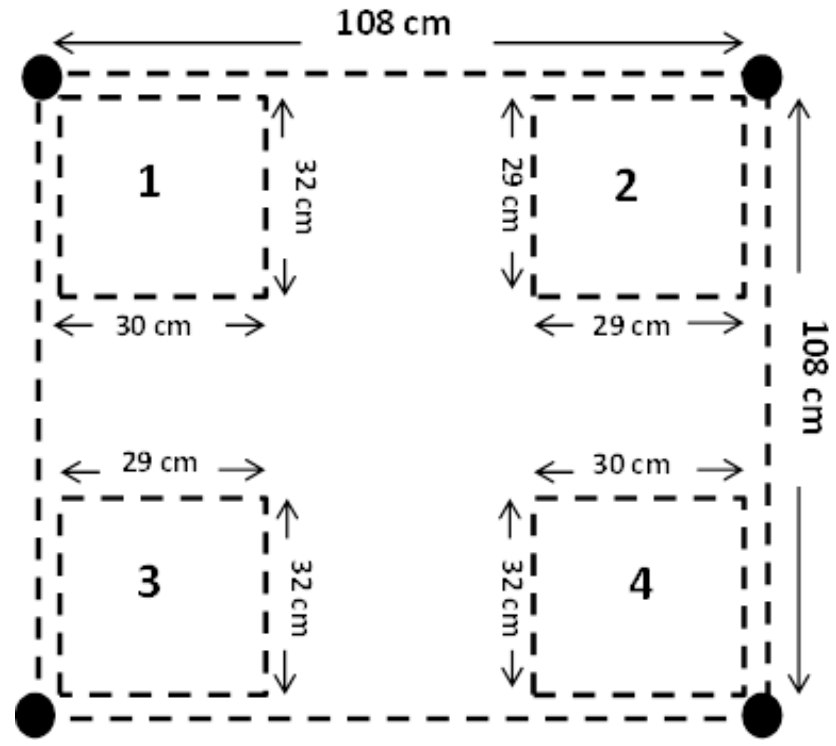

Fig. 2. Distribution of the subplots within the rainfall simulator wetting area.

\subsection{Data analysis}

A two-factor analysis of variance (Tukey's HSD $p<0.05$ ) was used to test for differences between the response by soil type and temperature (independent variable), for splash, $\mathrm{pH}$, EC, SOM, SAS and gypsum content (dependent variable), for each set of treatments. The separation of means was made according to Tukey's honestly significant difference test at an alpha level of 0.05 for all the parameters analyzed. Previous to ANOVA (analysis of variance), all variables were tested for normality using the Kolmogorov-Smirnov test. Percentage data (SOM, SAS and gypsum content) were transformed using arcsine of the square root and the others were $\ln$ transformed to improve the normality of the data. The analyses were performed using the RStudio version 3 statistical software (Robinson and Hamann, 2011).

\section{Results and discussion}

\subsection{Thermal shock}

The values of SOM, SAS and GC are significantly different for both soil types (see Table 1). The LP soil sample, placed on head slope, has lower SOM, SAS and higher GC than the GY soil sample, a more developed soil on foot slope with higher plant cover.

Heating significantly decreases $\mathrm{pH}$ and increases EC and soil loss by splash effect for both soil types $(p<0.05)$. The decrease in $\mathrm{pH}$ is highest at treatment of $205^{\circ} \mathrm{C}$, with $\mathrm{GY}$ being more susceptible to a decrease of $\mathrm{pH}$ than LP (7.8-7.9, respectively; Table 1). The EC increased significantly with temperature, especially at $205^{\circ} \mathrm{C}$, doubling its value (from 
Table 1. Mean value, standard deviation, mean comparison and their probability (ANOVA) according to the soils $(S)$, temperature $(T)$ and both $(S \times T)$, of the studied variable. $\left({ }^{* *}\right) p<0.001 ;\left(^{* *}\right) p<0.01 ;\left(^{*}\right) p<0.1$. For each soil property (line), different letters $(\mathrm{a}, \mathrm{b}, \mathrm{c})$ show significant differences $(P<0.05)$ among means, by post hoc Tukey test.

\begin{tabular}{|c|c|c|c|c|c|c|c|c|c|}
\hline \multicolumn{10}{|c|}{ Soil unit } \\
\hline Soil & \multicolumn{3}{|c|}{ Leptic Gypsisol } & \multicolumn{3}{|c|}{ Haplic Gypsisol } & \multicolumn{3}{|c|}{ Probability } \\
\hline Temp $\left({ }^{\circ} \mathrm{C}\right)$ & 25 & 105 & 205 & 25 & 105 & 205 & Soil $(S)$ & $\begin{array}{l}\text { Tempera- } \\
\text { ture }(T)\end{array}$ & $S \times T$ \\
\hline $\mathrm{pH}$ & $7.9 \pm 0.07 \mathrm{bc}$ & $7.9 \pm 0.00 \mathrm{c}$ & $7.8 \pm 0.04 \mathrm{~b}$ & $7.8 \pm 0.00 \mathrm{~b}$ & $7.8 \pm 0.06 \mathrm{bc}$ & $7.4 \pm 0.01 \mathrm{a}$ & $0.041^{*}$ & $0.039 *$ & $<0.001^{* * *}$ \\
\hline $\mathrm{EC}\left(\mathrm{mS} \mathrm{cm}^{-1}\right)$ & $2.1 \pm 0.01 \mathrm{a}$ & $2.1 \pm 0.00 \mathrm{a}$ & $4.2 \pm 0.18 b$ & $2.1 \pm 0.01 \mathrm{a}$ & $2.1 \pm 0.01 \mathrm{a}$ & $4.1 \pm 0.02 b$ & 0.974 & $<0.001^{* * *}$ & $<0.001^{* * *}$ \\
\hline $\operatorname{SOM}(\%)$ & $3.4 \pm 0.11 \mathrm{ac}$ & $3.3 \pm 0.03 \mathrm{ab}$ & $2.3 \pm 0.01 \mathrm{a}$ & $3.9 \pm 0.09 \mathrm{bc}$ & $4.8 \pm 0.14 \mathrm{c}$ & $4.5 \pm 0.11 b c$ & $<0.001^{* * *}$ & 0.506 & $0.003^{* *}$ \\
\hline SAS (\%) & $33.8 \pm 2.34 \mathrm{a}$ & $38.9 \pm 10.12 \mathrm{ab}$ & $35.7 \pm 1.61 \mathrm{ab}$ & $55.5 \pm 11.56 \mathrm{ab}$ & $60.7 \pm 1.44 b$ & $52.4 \pm 1.69 \mathrm{ab}$ & $<0.001^{* * *}$ & 0.868 & $0.025^{*}$ \\
\hline Gypsum (\%) & $39.9 \pm 2.13 \mathrm{c}$ & $46.2 \pm 0.87 \mathrm{c}$ & $45.0 \pm 4.60 \mathrm{c}$ & $15.5 \pm 1.52 \mathrm{ab}$ & $22.3 \pm 3.94 \mathrm{~b}$ & $11.1 \pm 0.34 \mathrm{a}$ & $<0.001^{* * *}$ & 0.983 & $<0.001^{* * *}$ \\
\hline Splash $\left(\mathrm{kg} \mathrm{m}^{-2}\right)$ & $0.5 \pm 0.3 \mathrm{a}$ & $0.7 \pm 0.2 \mathrm{a}$ & $0.5 \pm 0.5 \mathrm{a}$ & $0.8 \pm 0.2 \mathrm{a}$ & $0.6 \pm 0.2 \mathrm{a}$ & $1.4 \pm 0.2 \mathrm{a}$ & 0.384 & $0.014^{*}$ & 0.240 \\
\hline
\end{tabular}

$2.1 \mathrm{dS} \mathrm{m}^{-1}$ for $35^{\circ} \mathrm{C}$ to $4.2 \mathrm{dS} \mathrm{m}^{-1}$ for $205^{\circ} \mathrm{C}$, see Fig. 3). The SOM decreased significantly in the LP at a temperature of $205^{\circ} \mathrm{C}$ but not in GY topsoil, which can be related to SOM quality. The GY topsoil, more organic than the LP topsoil, is not significantly affected by the heat (Table 1). SAS was lower on LP than on GY, independent of the treatment $(33.8$ and $55.5 \%$, respectively), and the gypsum content in GY soil $(15.5 \pm 1.5 \%)$ is lower than in the LP soil $(39.9 \pm 2.1 \%)$. After heating, gypsum content undergoes a considerable decrease. Another remarkable difference between soils is that the water retention capacity available to plants is greater in the GY than LP topsoil (Fig. 4).

The statistical significance of all the relationships between the dependent variables (splash, $\mathrm{pH}, \mathrm{EC}, \mathrm{SOM}, \mathrm{SAS}$ and gypsum content) are given in Table 1 . The differences are not significantly different between the parameters with the same lowercase letter (i.e., the splash for both soil types). The statistical significance is shown by soil types (LP and GY) and temperature effect $\left(35,105\right.$ and $\left.205^{\circ} \mathrm{C}\right)$, and it was significant $(p<0.05)$, using the ANOVA. Notably, the temperature effect shows statistical significance for the $\mathrm{pH}, \mathrm{EC}$ and splash $(p<0.05)$.

In this study a small, but significant decrease was observed in $\mathrm{pH}$ at $205^{\circ} \mathrm{C}$ in both soils. This reduction could be a result of the oxidation, the exposure of new surfaces, the dehydration of colloids and the consequent decrease of the soil buffer action (Giovannini et al., 1990). Similar pH decrease was obtained by Badía and Martí (2003) after heating a gypseous soil at $250^{\circ} \mathrm{C}$.

Mineralogical components of these gypseous soils can be modified by heating above $50^{\circ} \mathrm{C}$ (Vieillefon, 1979; Herrero and Porta, 2000; Lebron et al., 2009) to transform the gypsum $\left(\mathrm{CaSO}_{4} \cdot 2 \mathrm{H}_{2} \mathrm{O}\right)$ into bassanite $\left(\mathrm{CaSO}_{4} \cdot 1 / 2 \mathrm{H}_{2} \mathrm{O}\right)$. The intensity of the changes in the soil depends on the temperature reached at different depths, on the duration of the heat pulse and the temperature peaks, and the stability of the various components of the soil (Gónzalez-Pérez et al., 2004; Terefe et al., 2008; Granged et al., 2011). Therefore the study was concentrated on the upper $6 \mathrm{~cm}$ of the soil samples. The range of heating $105-205^{\circ} \mathrm{C}$ was employed because during a fire only a small part of the heat is transmitted to the first few centimeters of soil (Badía et al., 2014). Pérez-Cabello et al. (2012) have recorded, maximum temperatures ranging from 400 to $800^{\circ} \mathrm{C}$ on the soil surface and $29-110^{\circ} \mathrm{C}$ in the upper soil centimeters $(6.5,2.5$ and $1 \mathrm{~cm}$ of soil depth). Other authors recorded $50{ }^{\circ} \mathrm{C}$ at $2.5 \mathrm{~cm}$ of depth under shrub and $90^{\circ} \mathrm{C}$ at the same depth under a less dense shrub (Luchessi et al., 1994). Aznar et al. (2013b) recorded $250^{\circ} \mathrm{C}$ at $1 \mathrm{~cm}$ depth and down to $150^{\circ} \mathrm{C}$ at $2 \mathrm{~cm}$ depth in a Gypsic Haploxerept soil (IUSS, 2007) in an experimental fire.

The increase of EC at $205^{\circ} \mathrm{C}$ may be related to solubilization and incorporation of cations from the ashes (Badía and Martí, 2003) or to the increased amount of soluble inorganic ions resulting from the combustion of soil organic matter (Certini, 2005). The trend of reduced SOM and SAS by heating in LP soil was explained by some authors (Cerdà, 1998; Giovannini, 2012) as caused by organic matter decline and the consequent destruction of aggregates and increased soil erodibility (Llovet et al., 2009; Mataix-Solera et al., 2011).

Increases in organic matter after low intensity fires (Mataix-Solera et al., 2011) may explain the increase in soil aggregate stability, even with the passage of time (BentoGonçalves et al., 2012; Martín et al., 2012). The reduction of soil aggregate stability after heating may be related to a decrease of soil organic matter (DeBano et al., 1998; Cerdà, 1998; Badía and Martí, 2003), and changes in the mineral composition of the soil (Varela et al., 2002). Giovannini (2012) observed that soil aggregate stability increased at about $150^{\circ}$ and again about $500^{\circ} \mathrm{C}$, from the combustion of the soil organic matter, as transformations of iron oxides cemented soil aggregates. Badía and Martí (2003) observed that organic matter in gypseous soils drops significantly from 2.8 to $2.2 \%$ when heated to $250^{\circ} \mathrm{C}$. This decrease is accompanied by a significant reduction of the structural stability from 70 to $50 \%$. Novara et al. (2011) observed a redistribution of the $\mathrm{OM}$ by water erosion and degradation at the upper part of the hillslopes. Despite the variety of results and explanations provided by different authors, similar values of $\mathrm{EC}, \mathrm{pH}, \mathrm{OM}$ and SAS have been found in other works in gypseous soils 

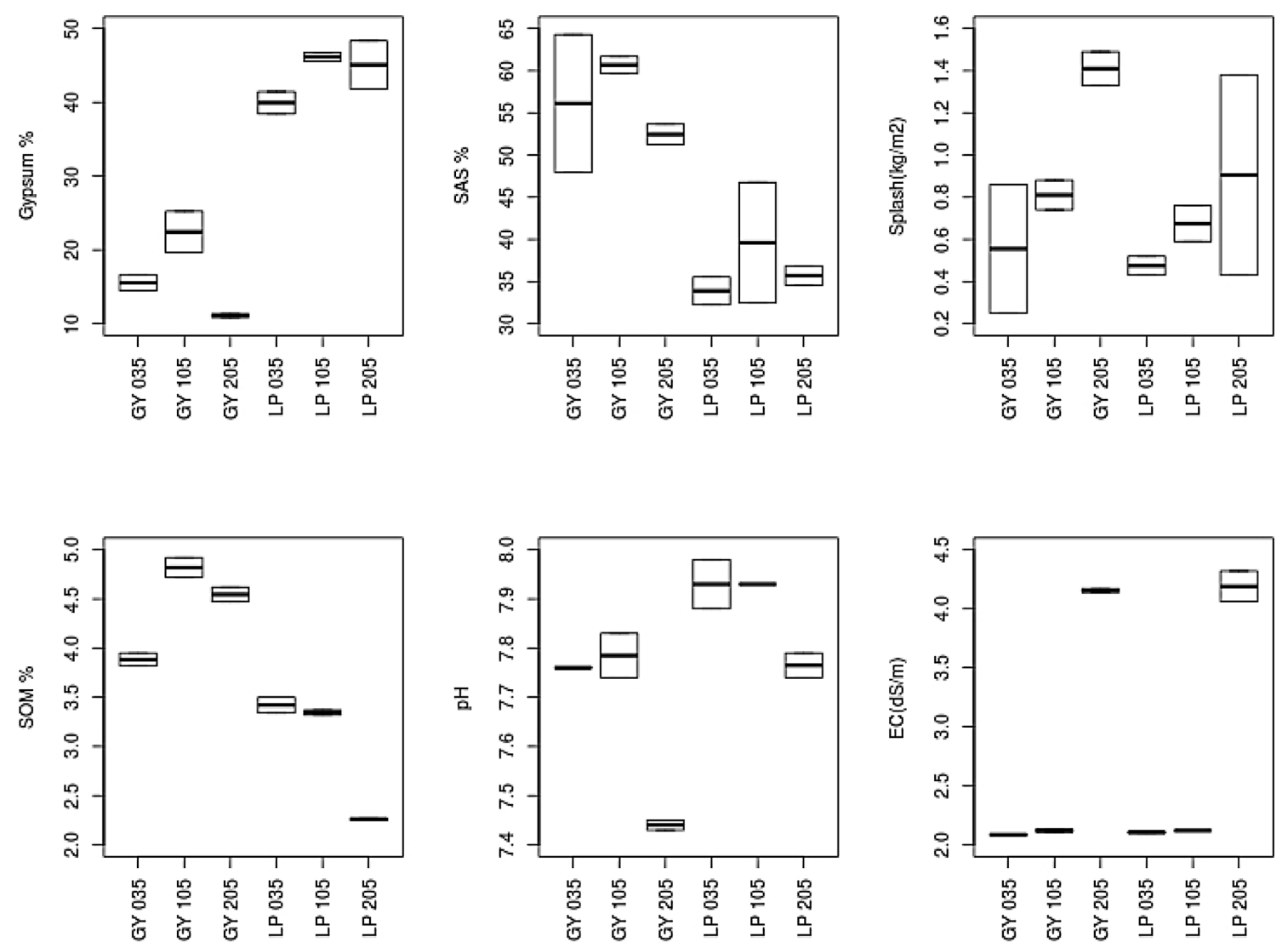

Fig. 3. Box plot of the soil properties.

(Badía and Martí, 2000, 2003; Cantón et al., 2001; Badía et al., 2008, 2013; Ries and Hirt, 2008; Lebron et al., 2009).

The water potential increases after heating at $105^{\circ} \mathrm{C}$ can relate to experimental fires of low intensity; the water retention values decrease both at the surface and at depth, and the bulk density increases in the outermost layer due to the reduction of micropores (Ralston and Hatchell, 1971; Boyer et al., 1994). Wahlenberg et al. (1939), observed in annual fires that bulk density increased and soil porosity was reduced due to aggregate dispersion by impact of rain, which can clog pores (Moehring et al., 1966; Cerdà and Doerr, 2005). Giovannini (2012) found a decrease in porosity in sandy soil when the temperature increased, most notably at $170-220^{\circ} \mathrm{C}$, and increases in bulk density and decreases of soil porosity related to the decrease of soil organic matter by soil heating. However, Mallik and Fitzpatrick (1996) concluded that soil porosity increased directly after fire.

\subsection{Mineralogical changes}

The main mineralogical component that is affected by heat is the gypsum. The gypsum content in the topsoil sample was higher in LP, than in GY (Tables 1 and 3). The gypsum content was higher in the Ahy horizon of LP than in the GY, as the gypsum content did not vary with heating at $105^{\circ} \mathrm{C}$ in both soils, but it was significantly reduced at $205^{\circ} \mathrm{C}$ in GY. The thermal increase transforms the gypsum into bassanite $\left(\mathrm{CaSO}_{4} \cdot 1 / 2 \mathrm{H}_{2} \mathrm{O}\right)$. In contrast, the LP soil with $50 \%$ gypsum in its fine earth fraction is partly transformed into bassanite when it was heated at $205^{\circ} \mathrm{C}$.

Bassanite could not be found in the samples heated at $105^{\circ} \mathrm{C}$, but it was in those heated at $205^{\circ} \mathrm{C}$. When the gypsum is heated up to $105^{\circ} \mathrm{C}$, only a small fraction (13-19\%) of gypsum is removed; moreover, subsequent partial rehydration in the laboratory results in the formation of bassanite at relative moisture below saturation (Lebron et al., 2009). Some data show that, at $105^{\circ} \mathrm{C}$, the gypsum crystal loses 13$19 \%$ of its mass (Artieda et al., 2006), corresponding to the two water molecules. Consequently Lebron et al. (2009) concluded that the temperature at which total water disappears is around $163^{\circ} \mathrm{C}$, since fast heating does not allow enough time for the water to diffuse through the crystal. For this reason in the mineralogical analysis bassanite did not show up until temperatures reached $205^{\circ} \mathrm{C}$.

\subsection{Splash effects}

The soil loss due to splash effect was higher in GY $\left(0.8 \pm 0.2 \mathrm{~kg} \mathrm{~m}^{-2}\right)$ than in LP soils $\left(0.5 \pm 0.3 \mathrm{~kg} \mathrm{~m}^{-2}\right)$. The first soil experienced a significant soil loss during the rainfall 


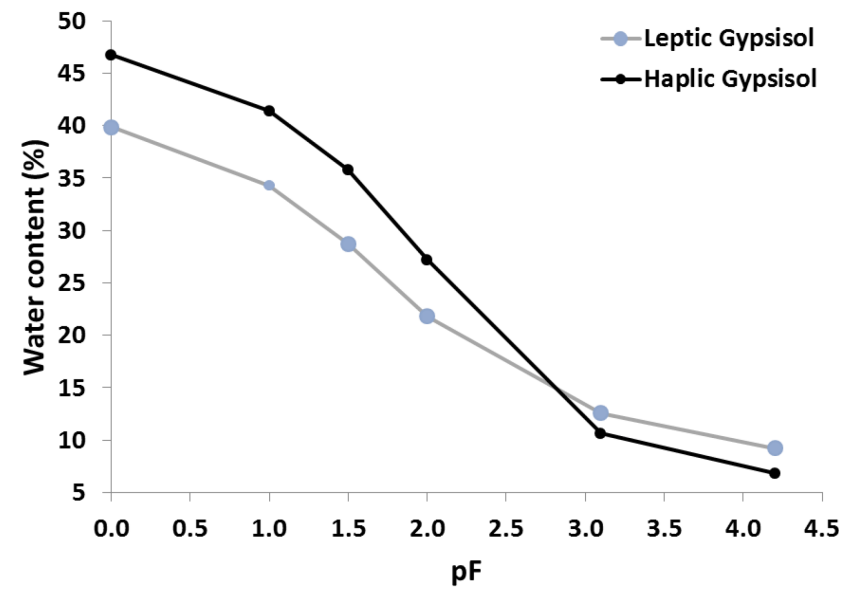

Fig. 4. Matric potential $(\mathrm{pF})$ values at collected samples from the field.

simulation experiment after heating $\left(1.4 \pm 0.2 \mathrm{~kg} \mathrm{~m}^{-2}\right)$, whilst the latter one was not sensitive to heating (Table 2).

The $\mathrm{pF}$ curve was similar for both soils, decreasing as the soil dries. The $\mathrm{pF}$ was higher in GY $(46.7 \pm 2.5)$ than in $\mathrm{LP}$ $(39.9 \pm 1.0)$ to values of 3 and $4.2 \mathrm{pF}$, and from here the trend is reversed. The LP soil $(9.2 \pm 2.4 \%)$ had higher $\mathrm{pF}$ than $\mathrm{GY}$ (6.8 \pm 0.3$)$ (Fig. 4).

The splash rates increased when soil aggregate stability (SAS) increased in LP $\left(0.5-0.7 \mathrm{~kg} \mathrm{~m}^{-2}\right)$. In GY the splash rates decreased when SAS increased $\left(0.6-1.4 \mathrm{~kg} \mathrm{~m}^{-2}\right)$ (Fig. 5).

There is no trend in the relationship between splash rate and soil organic matter. The splash rates increase when SOM decreases in LP $\left(0.5 \pm 0.5 \mathrm{~kg} \mathrm{~m}^{-2}\right)$. In GY the splash rates decrease when the SOM increases $\left(0.6 \pm 0.2 \mathrm{~kg} \mathrm{~m}^{-2}\right)$ (Fig. 6).

Splash erosion increases significantly by heating in GY but not in LP topsoil. The SAS and the splash rate are correlated positively in LP. While SAS is correlated negatively with the splash rate in GY (see Fig. 5), the soil aggregate stability is significantly correlated with soil type. In dry soil samples, crusting and cracking are detected, particularly in the LP. Herrero et al. (2009) explained that upon drying the salt migration is an important weathering process related to the formation and widening of crack and fissures, which can transmit additional water for further salt solution and crystallization. Splash production was higher in LP than in GY, in the samples heated at $105^{\circ} \mathrm{C}$; a possible explanation is that the SAS and SOM were lower in LP. The impact of raindrops on bare soil aggregates destroys the aggregates affected by fire (Moore and Singer, 1990; Fernández-Raga, 2013). Lower infiltration rates and higher surface runoff are explained by clogging pores and favoring entrainment of particles and nutrients, which may result in the formation of physical crusts (Mc Intyre, 1958; Mataix-Solera et al., 2011). Nevertheless, Bresson and Boiffin (1990) and Ries and Hirt (2008) did not

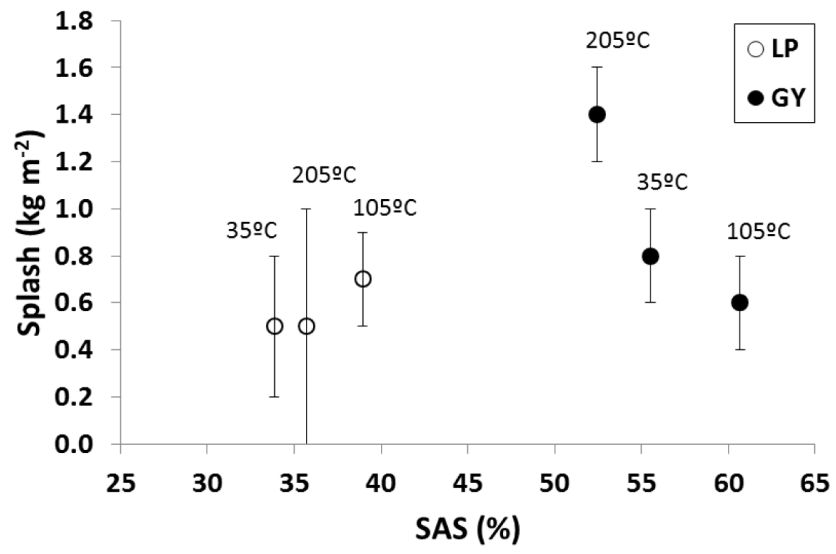

Fig. 5. Relationship between soil aggregate stability and splash erosion in both soils (means and standard deviations).

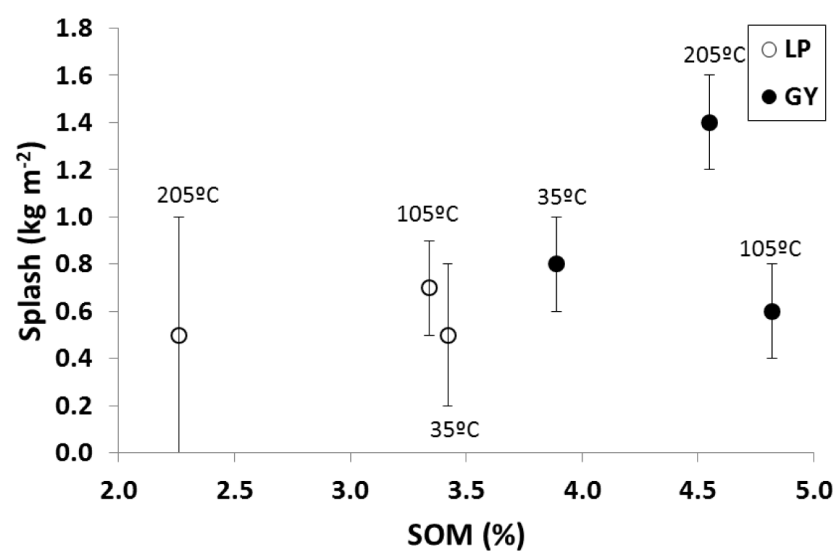

Fig. 6. Relationship between soil organic matter and splash erosion in both soils (means and standard deviations).

find any clear separation in inter-aggregates because of the short transport path or the transport via splash.

The difference between $\mathrm{pF} 3$ and $\mathrm{pF} 4.2$, indicating the amount of water capillary absorbable, has been reduced after wetting by rain and subsequent heating (see Table 2), but more experiments should be conducted to confirm these changes. The burned samples (GY) show a lower porosity (see Fig. 5), and the splash production is higher than in unburned samples (LP). However, the opposite occurs with the heated samples, because the porosity in GY is higher than in LP. Gypseous soil had a significantly low infiltration value, because the growth of gypsum crystals in pre-existing pores decreases water flow (Poch and Verplancke, 1997). The SOM and the splash rate are positively correlated in LP. While the soil aggregate stability with the splash rate is correlated negatively in GY to $105^{\circ} \mathrm{C}$, changing to positively at $205^{\circ} \mathrm{C}$ (Fig. 7). Moreover, gypseous soils have low organic matter content and aggregate stability that elicits a slow micropore flow (Martí et al., 2001). Lasanta et al. (2000) and Desir et al. (1995) observed the same results in similar soils 
Table 2. Mean value and standard deviation of the values of the $\mathrm{pF}$ (the base 10 logarithm of the water potential in centimeters). LP and GY before and after the rainfall simulation. $\left.{ }^{* *}\right)$ Difference between $\mathrm{pF} 4.2$ and $\mathrm{pF} 3$.

\begin{tabular}{|c|c|c|c|c|c|c|c|c|}
\hline \multicolumn{2}{|c|}{ Treatments } & \multicolumn{7}{|c|}{$\mathrm{pF}$} \\
\hline \multirow[t]{2}{*}{ Rainfall } & Temp & 0 & 1 & 1.5 & 2 & 3 & 4.2 & Dif.** \\
\hline & $\left({ }^{\circ} \mathrm{C}\right)$ & $0 \mathrm{kPa}$ & $1 \mathrm{kPa}$ & $5 \mathrm{kPa}$ & $10 \mathrm{kPa}$ & $100 \mathrm{kPa}$ & $1500 \mathrm{kPa}$ & Dif. ${ }^{* *}$ \\
\hline LP before & Field sample & $39.9 \pm 1.05$ & $34.3 \pm 2.12$ & $28.7 \pm 1.37$ & $21.8 \pm 0.78$ & $12.6 \pm 2.65$ & $9.2 \pm 2.48$ & 3.4 \\
\hline \multirow{3}{*}{ LP after } & 35 & 37.9 & 32.8 & 29.3 & 23.4 & $27.6 \pm 2.93$ & $19.6 \pm 0.30$ & 8.0 \\
\hline & 105 & 43.9 & 40.7 & 35.2 & 27.4 & $18.8 \pm 0.06$ & $15.0 \pm 0.02$ & 3.7 \\
\hline & 205 & 42.0 & 40.5 & 35.2 & 27.8 & $21.2 \pm 0.10$ & $17.4 \pm 0.13$ & 3.9 \\
\hline GY before & Field sample & $46.7 \pm 2.51$ & $41.4 \pm 1.69$ & $35.8 \pm 0.80$ & $27.2 \pm 0.31$ & $10.6 \pm 0.74$ & $6.8 \pm 0.38$ & 3.8 \\
\hline \multirow{3}{*}{ GY after } & 35 & 41.2 & 41.0 & 36.4 & 28.6 & $27.6 \pm 0.56$ & $15.0 \pm 0.24$ & 12.6 \\
\hline & 105 & 50.4 & 44.7 & 38.7 & 30.0 & $15.9 \pm 0.56$ & $11.9 \pm 0.13$ & 3.9 \\
\hline & 205 & 44.6 & 40.0 & 35.1 & 28.3 & $13.7 \pm 0.71$ & $10.0 \pm 0.24$ & 3.7 \\
\hline
\end{tabular}

Table 3. Mineralogy of the soil (2 $\mathrm{mm}$ mesh).

\begin{tabular}{lrrrrrrrr}
\hline & \multicolumn{5}{c}{ Soil mineralogy (\%) } \\
\hline Soil & \multicolumn{3}{c}{ Leptic Gypsisol } & & \multicolumn{3}{c}{ Haplic Gypsisol } \\
\cline { 2 - 3 } \cline { 7 - 9 } Temp $\left({ }^{\circ} \mathrm{C}\right)$ & 25 & 105 & 205 & & 25 & 105 & 205 \\
\hline Gypsum & 50 & 49 & 15 & & 26 & 7 & 0 \\
Bassanite & 0 & 0 & 33 & & 0 & 0 & 10 \\
Calcite & 4 & 0 & 2 & & 18 & 24 & 25 \\
Dolomite & 33 & 39 & 20 & & 23 & 28 & 27 \\
Quartz & 6 & 6 & 14 & & 19 & 24 & 20 \\
Feldspar & 0 & 0 & 0 & & 4 & 5 & 4 \\
Illite & 7 & 3 & 10 & & 10 & 8 & 10 \\
Kaolinite & 0 & 3 & 6 & & 0 & 4 & 4 \\
\hline
\end{tabular}

where a microcrust was developed. The precipitation as microcrystalline gypsum could relate to root channels, where the moisture conditions were different from those within the groundmass (Aznar et al., 2013a). The progressive loss of weigh could be due by dissolution of some soluble mineral within the sample in the wetting phase or by the enhanced dehydration of some mineral as a consequence of oven heating. When water dissolves gypsum, some new pore space increases the water intake in the following saturation phase and this progressive enlargement of pre-existing pore volume may enhance further weathering through solution (Cantón et al., 2001).

\section{Conclusions}

Heating decreases significantly the $\mathrm{pH}$ and increases $\mathrm{EC}$ and the splash erosion. SOM and SAS are not modified by moderate heating. The SOM, positively correlated with the SAS, is higher in the GY than in the LP topsoil according to their slope position and plant cover. Nonetheless soil loss by splash is three times higher in GY than in LP topsoil. Soil loss by splash increased significantly $(P<0.05)$ at $205^{\circ} \mathrm{C}$ only in GY topsoil. Heating at $205^{\circ} \mathrm{C}$ caused a partial dehydration of gypsum to bassanite in both gypseous soils (LP and GY).

Acknowledgements. This research was supported by the Ministry of Science and Innovation BES-2008-003056, the CETSUS project (CGL2007-66644-C04-04/HIDCLI) and the Geomorphology and Global Change Research Group (D.G.A., 2011). The Spanish Army has supported this work at the San Gregorio CENAF. We acknowledge the support by Catheline Stoff, for providing ideas, material and instruments. We thank Kevin Hyde for the final review of the manuscript.

Edited by: A. Cerdà

\section{References}

Artieda, O., Herrero, J., and Drohan, P. J.: A refinement of the differential water loss method for gypsum determination in soils, Soil Sci. Soc. Am. J., 70, 1932-1935, 2006.

Aznar, J. M., Poch, R. M., and Badía, D.: Soil catena along gypseous woodland in the middle Ebro Basin: soil properties and micromorphology relationships, Span. J. Soil Sci., 3, 28-44, 2013a.

Aznar, J. M., González-Pérez, J. A., Badía, D., and Martí, C.: At what depth are the properties of a gypseous forest topsoil affected by burning?, Land Degrad. Dev., doi:10.1002/ldr.2258, 2013 b. 
Badía, D. and Martí, C.: Seeding and mulching treatments as conservation measures of two burned soils in Central Ebro Valley, NE Spain, Arid Soil Res. Rehab., 14, 219-232, 2000.

Badía, D. and Martí, C.: Plant ash and heat intensity effects on chemical and physical properties of two contrasting soils, Arid Land Res. Manag., 17, 23-41, 2003.

Badía, D., Martí, C., Aguirre, J., Echeverría, M. T., and Ibarra, P.: Erodibility and hydrology of Arid Burned Soils: soil type and revegetation effects, Arid Land Res. Manag., 22, 286-295, 2008.

Badía, D., Martí, C., Aznar, J. M., and León, J.: Influence of slope and parent rock on soil genesis and classification in semiarid mountainous environments, Geoderma 193-194, 13-21, doi:10.1016/j.geoderma.2012.10.020, 2013.

Badía, D., Martí, C., Aguirre, J., Aznar, J. M., González-Pérez, J. A., De la Rosa, J., León, J., M., Echeverría, M. T., and Ibarra, P.: Wildfire effects on nutrients and organic carbon of a Rendzic Phaeozem in NE Spain: changes at $\mathrm{cm}$-scale topsoil, Catena, 113, 267-275, 2014.

Bento-Gonçalves, A., Vieira, A., Úbeda, X., and Martin, D.: Fire and soils: key concepts and recent avances, Geoderma, 191, 313, doi:10.1016/j.geoderma.2012.01.004, 2012.

Bodí, M. B., Doerr, S. H., Cerdà, A., and Mataix-Solera, J.: Hydrological effects of a layer of vegetation ash on underlying wettable and water repellent soil, Geoderma, 191, 14-23, 2012.

Bodí, M. B., Martin, D. A., Balfour, V. N., Santín, C., Doerr, S. H., Pereira, P., Cerdà, A., and Mataix-Solera, J.: Wildland fire ash: Production, composition and eco-hydro-geomorphic effects, Earth-Sci. Rev., 130, 103-127, 2014.

Boyer, W. D. and Miller, J. H.: Effects of burning and brush treatments on nutrient and soil physical properties in young long-leaf pine stands, Forest Ecol. Manag., 70, 311-318, 1994.

Bresson, L. M. and Boiffin, J.: Morphological characterization of soil crust development stages on an experimental field, Geoderma, 47, 301-325, 1990.

Cantón, Y., Solé-Benet, A., Queralt, I., and Pini, R.: Weathering of a gypsum-calcareous mudstone under semi-arid environment at Tabernas, SE Spain: laboratory and field-based experimental approaches, Catena, 44, 111-132, 2001.

Cerdà, A.: Changes in overland flow and infiltration after a rangeland fire in a Mediterranean scrubland, Hydrol. Process., 12, 1031-1042, 1998.

Cerdà, A. and Doerr, S. H.: The influence of vegetation recovery on soil hydrology and erodibility following fire: an eleven-year investigation, Int. J. Wildland Fire, 14, 423-437, 2005.

Cerdà, A. and Doerr, S. H.: The effect of ash and needle cover on surface runoff and erosion in the immediate post-fire period, Catena, 74, 256-263, doi:10.1016/S0341-8162(02)000279, 2008.

Cerdà, A. Giménez-Morera, A., and Bodí, M. B.: Soil and water losses from new citrus orchards growing on sloped soils in the western Mediterranean basin, Earth Surf. Proc. Land., 34, 18221830, doi:10.1002/esp.1889, 2009.

Certini, G.: Effects of fire on properties of forest soils: a review, Oecologia, 143, 1-10, 2005.

DeBano, L. F., Neary, D. G., and Ffolliot, P. F.: Fire's effects on ecosystems, John Wiley \& Sons, Inc., 1998.

Desir, G., Sirvent, J., Gutierrez, M., and Sancho, C.: Sediment yield from gypsiferous degraded áreas in the middle Ebro Basin, Phys. Chem. Earth, 20, 385-393, 1995.
Doerr, S. and Cerdà, A.: Fire effects on soil system functioning: new insights and future challenges, Int. J. Wildland Fire, 14 339-342, 2005.

Domínguez-Beisiegel, M., Herrero, J., and Castañeda, C.: Saline wetlands' fate in inland deserts: an example of 80 years' decline in Monegros, Spain, Land Degrad. Dev., 24, 250-265, doi:10.1002/ldr.1122, 2013.

Ellison, W. D.: Studies of raindrop erosion, Agr. Eng., 25, 131-136, 181-182, 1944.

FAO: Management of gypsiferous soils, Soils Bull. 62, FAO, Rome, 1990.

Fernández-Raga, M.: Splash erosion in recently-burnt area in North-West Spain, Geophys. Res. Abstracts, 15, EGU2013-216, 2013.

Fister, W., Iserloh, T., Ries, J. B., and Schmidt, R. G.: Comparison of rainfall characteristics of a small portable rainfall simulator and a portable wind and rainfall simulator, Z. Geomorphol., 55, 109-126, 2011.

Giovannini, G.: Fire in agricultural and forestal ecosystems: the effects on soil. Edizioni ETS, Pisa, Italy, 86 pp., 2012.

Giovannini, G., Lucchesi, S., and Giachetti, M.: Beneficial and detrimental effects of heating on soil quality, in: Fire in Ecosystem Dynamics - Mediterranean and Northern Perspectives. Third International Symposium on Fire Ecology, edited by: Goldammer, J. G. and Jenkins, M. J., Freiburg University, 95102, 1990.

González-Pérez, J. A., González-Vila, F. J., Almendros, G., and Knicker, H.: The effect of fire on soil organic matter - a review, Environ. Int., 30, 855-870, 2004.

Granged, A. J. P., Jordán, A., Zavala, L. M., and Bárcenas, G.: Fireinduced changes in soil water repellency increased fingered slow and runoff rates following the 2004 Huelva wildfire, Hydrol. Process., 25, 1614-1629, 2011.

Guénon, R., Vennetier, M., Dupuy, N., Roussos, S., Pailler, A., and Gros, R.: Trends in recovery of Mediterranean soil chemical properties and microbial activities after infrequent and frequent wildfires, Land Degrad. Dev., 24, 115-128, doi:10.1002/ldr.1109, 2013.

Gutiérrez, M. and Gutiérrez, F.: Geomorphology of the Tertiary gypsum formations in the Ebro Depression (Spain), Geoderma, 87, 1-29, 1998.

Herrero, J. and Porta, J.: The terminology and the concepts of gypsum-rich soils, Geoderma, 96, 47-61, 2000.

Herrero, J. and Snyder, R. L.: Aridity and irrigation in Aragon, Spain, J. Arid Environ., 35, 535-547, 1997.

Herrero, J., Artieda, O., and Hudnall, W. H.: Gypsum, a tricky material, Soil Sci. Soc. Am., 73, 1757-1763, 2009.

Hyde, K., Woods, S. W., and Donahue, J.: Predicting gully rejuvenation after wildfire using remotely sensed burn severity data, Geomorphology, 86, 496-511, 2007.

Iserloh, T., Ries, J. B., Cerdà, A., Echeverría, M. T., Fister, W., Geißler, C., Kuhn, N. J., León, F. J., Peters, P., Schindewolf, M., Schmidt, J., Scholten, T., and Seeger, M.: Comparative measurements with seven rainfall $\mathrm{s}$ simulators on uniform bare fallow land, Z. Geomorphol., 57, 11-26, 2012.

Keeley, J. E.: Fire intensity, fire severity and burn severity: a brief review and suggests usage, Int. J. Wildland Fire, 18, 116-126, 2009. 
Lasanta, T., García-Ruiz, J. M., Pérez-Rontomé, C., and SanchoMarcén, C.: Runoff and sediment yield in a semi-arid environment: the effect of land management after farmland abandonment, Catena, 38, 265-278, 2000.

Lebron, I., Herrero, J., and Robinson, D. A.: Determination of gypsum content in dryland soils exploiting the gypsum-bassanite phase change, Soil. Sci. Soc. Am. J., 73, 403-411, 2009.

León, F. J., Mataix-Solera, J., Echeverría, M. T., and Badía, D.: Wildfire effects and temporal changes of water repellency in a gypsiferous soils, Geophys. Res. Abstracts, 13, EGU2011-3978, 2011.

León, J., Echeverría, M. T., Badía, D., Martí, C., and Álvarez, C.: Effectiveness of Wood chips cover at reducing erosion in two contrasted burnt soils, Z. Geomorphol., 57, 27-37, 2013.

Llovet, J., Josa, R., and Vallejo, V. R.: Thermal shock and rain effects on soil surface characteristics: a laboratory approach, Catena, 74, 227-234, 2008.

Llovet, J., Ruiz-Valera, M., Josa, R., and Vallejo, V. R.: Soil responses to fire in Mediterranean forest landscapes in relation to the previous stage of land abandonment, Int. J. Wildland Fire, 18, 222-232, 2009.

Mallik, A. U. and Fitzpatrick, E. A.: Thin section studies of Calluna heathland soils subject to prescribed burning, Soil Use Manag., 12, 143-149, 1996.

Martí, C. Badía, D., and Buesa, M. A.: Aggregate stability in Altoaragón soils: comparison of wet steving and lab rainfall simulation methods, Edafología, 8, 21-30, 2001.

Martín, A., Díaz-Raviña, M., and Carballas, T.: Short- and mediumterm evolution of soil properties in Atlantic forest ecosystems affected by wildfires, Land Degrad. Dev., 23, 427-439, 2012.

Mataix-Solera, J. and Doerr, S. H.: Hydrophobicity and aggregate stability in calcareous topsoils from fire-affected pine forests in south-eastern Spain, Geoderma, 118, 77-88, 2004.

Mataix-Solera, J., Gómez, I., Navarro-Pedreño, J., Guerrero, C., and Moral, R.: Soil organic matter and aggregates affected by wildfire in a Pinus halepensis forest in Mediterranean environment, Int. J. Wildland Fire, 11, 107-114, 2002.

Mataix-Solera, J., Cerdà, A., Arcenegui, V., Jordán, A., and Zavala, L. M.: Fire effects on soil aggregation: A review, Earth-Sci. Rev., 109, 44-60, 2011.

Mc Intyre, D. S.: Soil splash and the formation of surface crust by raindrop impact, Soil Sci., 85, 261-266, 1958.

Moehring, D. M., Grano, C. X., and Basset, J. R.: Properties of forested loess soils after repeated prescribed burns, US For. Serv. Res. Note, SO-40, 4 pp., 1966.

Moore, D. C. and Singer, M. J.: Crust formation effects on soil erosion processes, Soil Soc. Am. J., 54, 1117-1123, 1990.

Nadal-Romero, E., Torri, D., and Yair, A.: Updating the badlands experience, Catena, 106, 1-3, 2013.

Neary, D. G., Klopatek, C. C., DeBano, L. F., and Ffolliot, P.: Fire effects on belowground sustainability: a review and synthesis, Forest Ecol. Manag., 122, 51-71, 1999.

Novara, A., Gristina, L., Bodí, M. B., and Cerdà, A.: The impact of fire on redistribution of soil organic matter on a mediterranean hillslopes under maquia vegetation type, Land Degrad. Dev., 22, 530-536, 2011.

Pereira, P., Cerdà, A., Úbeda, X., Mataix-Solera, J., Martin, D., Jordán, A., and Burguet, M.: Spatial models for monitoring the spatio-temporal evolution of ashes after fire - a case study of a burnt grassland in Lithuania, Solid Earth, 4, 153-165, 2013.

Pérez-Cabello, F., Cerdà, A., de la Riva, J., Echeverría, M. T., García-Martín, A., Ibarra, P., Lasanta, T., Montorio, R., and Palacios, V.: Micro-scale post-fire surface cover changes monitored using high spatial resolution photography in a semiarid environment: A useful tool in the study of post-fire soil erosion processes, J. Arid Environ., 76, 88-96, 2012.

Poch, R. M. and Verplancke, H.: Penetration resistance of gypsiferous horizons, Eur. J. Soil Sci., 48, 535-543, 1997.

Poesen, J. W. A. and Nearing, M. A.: Soil surface sealing and crusting, Catena Supplement 24, Catena Verlag, Cremlinge-Destedt, Germany, 1993.

Prats, S. A., Malvar, M. C., Simões-Vieira, D. C., MacDonald, L., and Keizer, J. J.: Effectiveness of hydromulching to reduce runoff and erosion in a recently burnt pine plantation in central Portugal, Land Degrad. Dev., doi:10.1002/ldr.2236, 2013.

Ralston, C. W. and Hatchell, G. E.: Effect of prescribed burning on physical properties of soil, in: Proceedings, Prescribed Burning Symposium, 14-16 April 1971, Charleston SC. US. For. Serv. Southeastern For. Exp. Stn., Asheville, NC, 68-85, 1971.

Ramos, M. C., Nacci, S., and Pla, I.: Effects of raindrop impact and its relationship with aggregate stability to different disaggregation forces, Catena, 53, 365-376, 2003.

Ries, J. B. and Hirt, U.: Permanence of soil surface on abandoned farmland in the Central Ebro Basin/Spain, Catena, 72, 282-296, 2008.

Riley, K. L., Bendick, R., Hyde, K. D., and Gabet, E. J.: Frequencymagnitude distribution of debris flows compiled from global data, and comparison with post-fire debris flows in the western U.S., Geomorphology, 191, 118-128, 2013.

Robinson A. P. and Hamann J. D.: Forest Analytics with R. Use R! Springer, ISBN 978-1-4419-7761-8, 2011.

Ruiz, J.: Mapa forestal de España. Hoja 7-4: Zaragoza. E. 1:200.000. Ed. Icona-MAPA, Madrid, 1990.

Schinner, F., Ohlinger, R., Kandeler, E., and Margesin, R.: Methods in soil biology, Springer-Verlag, Berllin, 1996.

Seeger, M.: Uncertainty of factors determining runoff and erosion processes as quantified by rainfall simulations, Catena, 71, 5667, 2007.

Shakesby, R. A.: Post-wildfire soil erosion in the Mediterranean: Review and future research directions, Earth Sci. Rev., 105, 71100, 2011.

Taubner, H., Roth, B., and Tippkotter, R.: Determination of soil texture: comparison of the sedimentation method and the laserdiffraction analysis, J. Plant Nutr. Soil Sci., 172, 161-171, 2009.

Terefe, T., Mariscal-Sancho, I., Peregrina, F., and Espejo, R.: Influence of heating on various properties of six Mediterranean soils. A laboratory study, Geoderma, 143, 273-280, 2008.

Ulery, A. L., Graham, R. C., and Amrhein, C.: Wood-ash composition and soil $\mathrm{pH}$ following intense burning, Soil Sci., 156, 358364, 1993.

Varela, M. E., de Blas, E., Benito, E., and López, I.: Changes induced by forest fires in the aggregate stability and water repellency of soils in NW Spain, in: Forest Fire Research \& Wildland Fire Safety, edited by: Viegas, D. X., Ed. Millpress, Rotterdam, 2002. 
Verheye, W. H. and Boyadgiev, T. G.: Evaluating the land use potential of gypsiferous soils from field pedogenic characteristics, Soil Use Management, 13, 97-103, 1997.

Vieillefon, J.: Contribution a l'amélioration de l'étude analytique des sols gypseux, Cahiers ORSTOM, Pédologie, 17, 195-223, 1979.
Wahlenberg, W. G., Greene, S. W., and Reed, H. R.: Effects of fire and cattle grazing on longleaf pine lands as studied at McNeill, Mississippi, US Dep. Agr. Tech. Bull., 683, 52 pp., 1939. 